costs, improved asset utilization, and improved margins. With perceived quality, your products and services have greater value, your market share increases, revenues grow, and profitability is improved.

\section{CONCLUSION}

Since 1990, the Baldrige criteria have provided UMH with a structure and road map for change and improvement. Since 1990, four cycles of selfassessment using the Baldrige criteria have enabled the leadership of UMH to identify the areas throughout the hospitals that present the greatest opportunity for improvement. It is our hope the feedback report from the State of Michigan Quality Leadership Award will help us focus our change efforts. From this experience, we are confident that the extension of the Baldrige Award nationally will add value to the healthcare system. We encourage healthcare professionals to embrace and support the Health Care Pilot Program in 1995. It will present new opportunities for knowledge sharing across the healthcare system nationally. Finally, in an area of change and competition, the expansion into health care also will help to establish uniform quality assessment tools across industries and will allow customers in other industries to better understand healthcare quality approaches in the future.

$M$ ore information about the Baldrige A ward, as well as copies of the $1995 \mathrm{H}$ ealth Care Pilot Criteria, may be obtained by contacting the $\mathrm{M}$ alcolm Baldrige $\mathrm{N}$ ational Q uality A ward, $\mathrm{N}$ ational Institute of Standards and Technology, Route 270 and Quince 0 rchard Rd., Administration Bldg., Room A 537, Gaithersburg,
M D 20899-0001; telephone (301) 975-2036, fax (301) 948-3716.

\section{REFERENCES}

1. Senge PM. The Fifth Discipline: The Art and Practice of the Learning Organization. New York, NY: Doubleday; 1990:4.

2. Juran J. The upcoming century of quality. In: Quality Progress. 1994:32.

3. US Department of Commerce. U nited States Commerce Department News. October 20, 1994:1.

4. Betting to win on the baldy winners. Business Week. October 18, 1993:8.

5. US General Accounting O ffice M anagement Practices: U S Companies Improve Performance Through Quality Efforts. Report to the Honorable Donald Ritter, House of Representatives, GAO/ NSLAD-91-190 Management Practices. Washington, DC: National Security and International Affairs Division, US General Accounting Office; 1991.

6. National Institute of Standards and Technology. 1994 A ward Criteria: Malcolm Baldrige National Quality Award. Gaithersburg, MD: National Institute of Standards and Technology, United States Department of Commerce; 1994.

7. Hertz HS, Reimann CW, Bostwick MC. The Malcolm Baldrige National Quality Award concept: could it help stimulate or accelerate healthcare improvement? Quality $M$ anagement in H ealth Care 1994;2(4):63-72.

8. Keers SC. Baldrige for healthcare in works. Healthcare Informa tion and M anagement Systems Society N ews 1994;5:1.

9. George S, Weimerskirch A. Total Quality M anagement: Strategies and Techniques Proven at Todays M ost Success\& I Companies. New York, NY: John Wiley and Sons, Inc.; 1994:242.

10. Kratochwill EW, Gaucher EJ. Using the Baldrige criteria as a self-assessment tool: a case study from the University of Michigan Medical Center. The Journal of the Healthcare Information and $M$ anagement Systems Society 1994;8(4):25-33.

11. George S, Weimerskirch A. Total Q uality Management: Strategies and Techniques Proven at Today's M ost Successful Companies. New York, NY: John Wiley and Sons, Inc; 1994:8.

\title{
CDC Implements First Phase of Plan to Address Emerging Infections
}

\section{by Gina Pugliese, RN, MS Medical News Editor}

The Centers for Disease Control and Prevention (CDC) recently began a national surveillance network in four states to identify new pathogens, resistant organisms, and organisms causing invasive diseases. The four network surveillance sites that have been chosen to begin the emerging infections program (EIP) will be in the state health departments of Sacramento, California; Hartford, Connecticut; Minneapolis, Minnesota; and Portland, Oregon. All the programs will be linked to the university and teaching hospitals in their respective states and will conduct laboratory surveillance for invasive bacterial disease caused by $\mathrm{H}$ aemophilus injluenzae, $\mathrm{N}$ eisseria meningitidis, Groups A and B streptococci, and antibiotic-resistant pneumococci. In addition, all sites will be conducting surveillance for unexplained deaths caused by infections, as well as cases of Clostridium difficile to assess its role as a nosocomial and community pathogen.

Certain network sites will be focused on specific infections. For example, Hartford will follow community-acquired pneumonia and analyze risk for Ehrlichia, Minneapolis will focus on foodborne illness and cryptosporidiosis, and Portland will collect data on cases of meningitis caused by a rare US strain of streptococcus, Group B type ET5. The network epidemiologists in California will collect data on vancomycin-resistant enterococci at 45 hospitals in San Francisco, including data on the efficacy of laboratory identification and infection control measures.

Grants were awarded to each site from the $\$ 6.7$ million allocated to implement EIP

FROM: Hospital Infection Control. March 1995, and AMA News February 6, 1995. 